\title{
KONTRIBUSI SUB SEKTOR PERKEBUNAN DALAM PEREKONOMIAN KABUPATEN MINAHASA UTARA
}

\section{CONTRIBUTION OF THE PLANTATION SUB-SECTOR TO THE ECONOMY OF NORTH MINAHASA REGENCY}

\author{
Karla Meray_(1), Tommy F. Lolowang ${ }^{(2)}$, Juliana R. Mandei ${ }^{(2)}$
}

1) Mahasiswa Program Studi Teknologi Pangan, Fakultas Pertanian, Universitas Sam Ratulangi, Manado

2) Dosen Program Studi Teknologi Pangan, Fakultas Pertanian, Universitas Sam Ratulangi, Manado

*Penulis untuk korespondensi: karlameray@gmail.com

\begin{tabular}{ll}
\hline Naskah diterima melalui e-mail jurnal ilmiah agrisosioekonomi@unsrat.ac.id & : Selasa, 6 April 2021 \\
Disetujui diterbitkan & : Jumat, 28 Mei 2021 \\
\hline
\end{tabular}

\begin{abstract}
The purpose of this research is to see plantation sectoral contribution on North Minahasa Regency economic development. This research was conducted in July 2020. The data used in this study are secondary data. Data were obtained from North Minahasa Regency's Central Burean of Statistics and North Minahasa Province's Central Burean of Statistics. This research used basis of Constant Price Gross Regional Domestic Product from 2010 to 2019, land area and plantation productions of North Minahasa Regency. This study uses data analysis methods, namely location quotient analysis, shift share, and contribution analysis. The results of the research showed that plantation sub-sector is basic sector in North Minahasa Regency and had $L Q$ value more that 1 and be able to produce goods and services for local consumption as well as exportation. Shift share analysis showed that in year of 20102019 plantation sectoral didn't have competitive advantage, but it has positif effect and a good growth rate for the economy of North Minahasa.
\end{abstract}

Keywords : Plantation sub-sector; contribution; North Minahasa Regency

\section{ABSTRAK}

Tujuan penelitian ini adalah untuk melihat kontribusi dan perkembangan sub-sektor perkebunan terhadap perekonomian Kabupaten Minahasa Utara. Data yang digunakan dalam penelitian ini adalah data sekunder. Data diperoleh dari Badan Pusat Statistik (BPS) Kabupaten Minahasa serta Badan Pusat Statistik (BPS) Provinsi Sulawesi Utara. Data yang digunakan adalah PDRB ADHK 2010 sampai 2019 serta luas lahan dan produksi perkebunan Kabupaten Minahsa Utara. Penelitian ini menggunakan metode analisis data yaitu analisi location quotient, shift share, dan analisis kontribusi. Hasil penelitian menunjukkan bahwa sub sektor perkebunan merupakan sektor basis di Kabupaten Minahasa Utara dan memiliki nilai LQ lebih dari 1 dan mampu manghasilkan barang dan jasa untuk konsumsi lokal maupun mengekspor keluar wilayah. Dari hasil analisis perhitungan Shift Share meski sub-sektor perkebunan tidak memiliki keunggulan kompetitif untuk tahun 2011- 2019 namun memberi pengaruh positif dan laju pertumbuhan yang baik untuk perekonomian Minahasa Utara.

Kata Kunci : Sub sektor perkebunan; kontribusi; Kabupaten Minahasa Utara

Agrisosioekonomi:Jurnal Transdisiplin Pertanian (Budidaya Tanaman, Perkebunan, Kehutanan, Peternakan, Perikanan), Sosial Ekonomi dan Teknologi Pangan serta Teknologi Pertanian 


\section{PENDAHULUAN}

Proses Pembangunan ekonomi daerah berjalan di mana pemerintah daerah dan masyarakatnya mengelola sumber daya yang ada dan membentuk suatu pola kemitraan antara pemerintah daerah dan sektor swasta untuk menciptakan lapangan kerja baru dan merangsang perkembangan kegiatan ekonomi (pertumbuhan ekonomi) dalam wilayah tersebut (Zaini, 2019)
Sektor pertanian merupakan salah satu sektor penting untuk diperhatikan karena sebagian besar mata pencaharian penduduk berada pada sektor ini. Sektor pertanian meliputi subsektor tanaman bahan makanan, subsektor hortikultura, subsektor perkebunan, subsektor peternakan, subsektor perikanan dan subsektor kehutanan. Subsektorsubsektor ini akan saling terkait untuk saling mendukung kemajuan antar subsektor (Suryantini dkk, 2015).

Tabel 1. Luas Areal Perkebunan dan Jenis Tanaman di Kabupaten Minahasa Utara (hektar)

\begin{tabular}{|c|c|c|c|c|c|c|c|c|c|c|}
\hline Komoditas & 2010 & 2011 & 2012 & 2013 & 2014 & 2015 & 2016 & 2017 & 2018 & 2019 \\
\hline Kelapa & 33397.62 & 35438 & 35231.17 & 44120.1 & 44062.22 & 42763.13 & 42702.77 & 44876.93 & 36389.73 & 36642.70 \\
\hline Kopi & 46.02 & 0 & 46.02 & 50.44 & 50.44 & 50.44 & 0 & 0 & 0 & 0 \\
\hline Kakao & 71.93 & 0 & 102.7 & 501.7 & 501.7 & 501.7 & 0 & 27.59 & 0 & 0 \\
\hline Cengkeh & 2257.79 & 2258 & 2232.79 & 3069.29 & 3069.29 & 3069.29 & 3069.29 & 2730.86 & 2699.99 & 0 \\
\hline Pala & 641.81 & 642 & 641.81 & 1831.04 & 2041.04 & 1841.91 & 2026.91 & 1779.45 & 2629.24 & 0 \\
\hline Vanili & 0 & 0 & 69.86 & 185.57 & 185.57 & 185.57 & 185.57 & 0 & 0 & 0 \\
\hline $\begin{array}{l}\text { Jambu } \\
\text { Mede }\end{array}$ & 0 & 0 & 196.98 & 140.49 & 112.99 & 112.99 & 35.48 & 0 & 0 & 0 \\
\hline Aren & 0 & 0 & 448.16 & 698.71 & 698.71 & 698.71 & 698.71 & 0 & 0 & 0 \\
\hline Jumlah & 36415.17 & 38338 & 38969.49 & 50597.34 & 50721.96 & 49223.74 & 48718.73 & 49414.83 & 41718.96 & 36642.70 \\
\hline
\end{tabular}

Di Kabupaten Minahasa Utara sektor pertanian berperan besar terhadap PDRB Kabupaten Minahasa Utara, menambah devisa dan memacu pertumbuhan wilayah. Sektor pertanian mencakup beberapa kategori ini pertanian, kehutanan dan perikanan yang terdiri atas tanaman pangan, tanaman hortikultura, tanaman perkebunan, peternakan, dan jasa pertanian dan perburuan.

Dengan potensi Sumber Daya Alam (SDA) yang dimiliki Kabupaten Minahasa Utara, perkebunan dengan beberapa jenis komoditas perkebunan seperti Kelapa, Cengkeh dan Pala merupakan sub sektor yang cocok dikembangkan di daerah ini. Namun dalam beberapa tahun terakhir seperti terlihat pada Tabel 1, luas lahan beberapa tanaman perkebunan pada beberapa tahun terakhir cenderung menurun. Oleh karena itu menarik untuk diteliti tentang "Kontribusi Sub Sektor Perkebunan Dalam Perekonomian Kabupaten Minahasa Utara”.

\section{Rumusan Masalah}

Berdasarkan latar belakang yang telah di uraikan di atas adapun rumusan masalah:

1) Bagaimana kontribusi sektor perkebunan terhadap perekonomian Kabupaten Minahasa Utara?

\section{Tujuan Penelitian}

Penelitian ini bertujuan untuk :

1) Menganalisis kontribusi sektor perkebunan terhadap perekonomian Kabupaten Minahasa Utara menggunakan penerapan analisis location quotient dan shift share.

2) Menganalisis perkembangan sektor perkebunan dalam perekonomian Kabupaten Minahasa Utara.

\section{METODE PENELITIAN}

\section{Metode Pengumpulan Data}

Jenis data yang digunakan dalam penelitian ini adalah data sekunder. Data diperoleh dari Badan Pusat Statistik (BPS) Kabupaten Minahasa serta Badan Pusat Statistik (BPS) Provinsi Sulawesi Utara. Data yang digunakan adalah PDRB 2010 sampai 2019 ADHK serta luas lahan dan produksi perkebunan Kabupaten Minahsa Utara.

\section{Variabel Penelitian}

Variabel-variabel yang diukur dalam penelitian ini, adalah :

1) Luas areal perkebunan Kabupaten Minahasa Utara

2) Produksi perkebunan Kabupaten Minahasa Utara 
3) Luas areal perkebunan Sulawesi Utara

4) Produksi perkebunan Sulawesi Utara

5) Produk Domestik Regional Bruto sektorsektor (ADHK) Kabupaten Minahasa Utara

6) Produk Domestik Regional Bruto sektorsektor (ADHK) Sulawasi Utara

7) Produk Domestik Regional Bruto sektor perkebunan (ADHK) Kabupaten Minahasa Utara

8) Produk Domestik Regional Bruto sektor perkebunan (ADHK) Sulawasi Utara

\section{Metode Analisis}

Untuk penelitian ini digunakan dua metode analisis data yaitu analisi location quotient, shift share, dan analisis kontribusi.

\section{HASIL DAN PEMBAHASAN}

\section{Deskripsi Umum Lokasi Penelitian}

Kabupaten Minahasa Utara dengan pusat pemerintahan dan ibu kota di Airmadidi, terletak di Provinsi Sulawesi Utara. Kabupaten Minahasa Utara terdiri dari 10 Kecamatanterdiri dari 10 Kecamatan dengan jumlah penduduk tahun 2019 sebanyak 203.624 jiwa yang terdiri atas 103.411 jiwa penduduk laki-laki dan 100.213 jiwa penduduk perempuan.

\section{Kontribusi Perkebunan Terhadap Perekonomian Kabupaten Minahasa Utara}

1) Hasil Analisis Location Quotient

Tabel 2 menjelaskan bahwa sektor pertanian merupakan salah satu sektor basis yang di Kabupaten Minahasa Utara dengan nilai LQ pada tahun 20191.24 meski mengalami fluktuasi selama 10 tahun pada periode 2010-2019.

Dari Tabel 2 dapat dilihat ada 7 sektor yang merupakan sektor basis dari perhitungan LQ tahun 2010-2019 antara lain pertanian, kehutanan, dan perikanan, pertambangan dan penggalian, industri pengolahan, pengadaan listrik dan gas, konstruksi, real estate, jasa pendidikan. Ini artinya bahwa 7 sektor tersebut merupakan sumber pertumbuhan ekonomi, memiliki keunggulan komparatif, dapat memenuhi kebutuhan kabupaten serta dapat melakukan ekspor . Selain luas lahan dan produksi yang mempengaruhi kenaikan dan penurunan nilai LQ sektor perkebunan, kenaikan dan penurunan sektor lainnya juga mempengaruhi. Seperti periode tahun 2011-2013 sektor perkebunan mengalami penurunan nilai LQ yang diakibatkan dari sektor pertambangan dan penggalian yang mengalami peningkatan nilai LQ serta beberapa sub sektor pertanian seperti tanaman hortikultura, peternakan serta perikanan terus mengalami peningkatan nilai LQ.

Tabel 2. Hasil Perhitungan Location Quotient Perkebunan dan Lapangan Usaha

\begin{tabular}{|c|c|c|c|c|c|c|c|c|c|c|}
\hline $\begin{array}{c}\text { Lapang Usaha } \\
\text { Pertanian, Kehutanan, dan Perikanan }\end{array}$ & $\frac{2010}{1.31}$ & $\begin{array}{c}2011 \\
1.34\end{array}$ & $\frac{2012}{1.35}$ & $\begin{array}{c}2013 \\
1.34\end{array}$ & $\begin{array}{c}2014 \\
1.35\end{array}$ & $\begin{aligned} 2015 \\
1.29\end{aligned}$ & $\begin{array}{c}2016 \\
1.25\end{array}$ & $\begin{aligned} 2017 \\
1.23\end{aligned}$ & $\begin{array}{cl}2018^{*} \\
1.23\end{array}$ & $\frac{2019 * *}{1.24}$ \\
\hline - Perkebunan & 1.29 & 1.32 & 1.30 & 1.18 & 1.19 & 1.15 & 1.12 & 1.12 & 1.14 & 1.12 \\
\hline Pertambangan dan Penggalian & 2.07 & 2.07 & 2.08 & 2.13 & 2.12 & 2.23 & 2.24 & 2.25 & 2.29 & 2.30 \\
\hline Industri Pengolahan & 1.26 & 1.27 & 1.27 & 1.27 & 1.28 & 1.43 & 1.42 & 1.43 & 1.46 & 1.45 \\
\hline Pengadaan Listrik dan Gas & 1.16 & 1.17 & 1.15 & 1.15 & 1.10 & 1.45 & 1.51 & 1.36 & 1.39 & 1.38 \\
\hline $\begin{array}{l}\text { Pengadaan Air, Pengelolaan Sampah, Limbah dan Daur } \\
\text { Ulang }\end{array}$ & 0.59 & 0.59 & 0.59 & 0.59 & 0.58 & 0.60 & 0.60 & 0.60 & 0.62 & 0.62 \\
\hline Konstruksi & 1.05 & 1.04 & 1.07 & 1.05 & 1.08 & 1.24 & 1.32 & 1.33 & 1.29 & 1.29 \\
\hline $\begin{array}{l}\text { Perdagangan Besar dan Eceran; Reparasi Mobil dan } \\
\text { Sepeda Motor }\end{array}$ & 0.77 & 0.75 & 0.74 & 0.74 & 0.74 & 0.77 & 0.79 & 0.78 & 0.77 & 0.75 \\
\hline Transportasi dan Pergudangan & 0.50 & 0.51 & 0.51 & 0.51 & 0.50 & 0.40 & 0.39 & 0.40 & 0.40 & 0.40 \\
\hline Penyediaan Akomodasi dan Makan Minum & 0.48 & 0.49 & 0.48 & 0.48 & 0.48 & 0.48 & 0.49 & 0.49 & 0.51 & 0.53 \\
\hline Informasi dan Komunikasi & 0.47 & 0.45 & 0.45 & 0.45 & 0.45 & 0.54 & 0.55 & 0.53 & 0.54 & 0.55 \\
\hline Jasa Keuangan dan Asuransi & 0.23 & 0.23 & 0.22 & 0.21 & 0.21 & 0.21 & 0.22 & 0.24 & 0.24 & 0.24 \\
\hline Real Estate & 1.52 & 1.53 & 1.53 & 1.53 & 1.53 & 1.63 & 1.70 & 1.75 & 1.77 & 1.83 \\
\hline Jasa Perusahaan & 0.20 & 0.20 & 2.02 & 0.20 & 0.20 & 0.19 & 0.19 & 0.18 & 0.17 & 0.17 \\
\hline $\begin{array}{l}\text { Administrasi Pemerintahan, Pertahanan dan Jaminan } \\
\text { Sosial Wajib }\end{array}$ & 0.53 & 0.55 & 0.54 & 0.57 & 0.57 & 0.48 & 0.49 & 0.45 & 0.43 & 0.43 \\
\hline Jasa Pendidikan & 1.08 & 1.10 & 1.10 & 1.12 & 1.12 & 0.98 & 1.02 & 1.06 & 1.06 & 1.03 \\
\hline Jasa Kesehatan dan Kegiatan Sosial & 0.73 & 0.72 & 0.71 & 0.71 & 0.70 & 0.76 & 0.77 & 0.78 & 0.78 & 0.78 \\
\hline Jasa lainnya & 0,40 & 0,40 & 0,40 & 0,40 & 0.39 & 0.41 & 0.41 & 0.40 & 0.38 & 0.35 \\
\hline
\end{tabular}

Agrisosioekonomi:Jurnal Transdisiplin Pertanian (Budidaya Tanaman, Perkebunan, Kehutanan, Peternakan, Perikanan), Sosial Ekonomi dan Teknologi Pangan serta Teknologi Pertanian 
Tabel 3. Hasil Perhitungan Location Quotient Sub Sektor Pertanian di Minahasa Utara

\begin{tabular}{|c|c|c|c|c|c|c|c|c|c|c|}
\hline Lapangan Usaha & 2010 & 2011 & 2012 & 2013 & 2014 & 2015 & 2016 & 2017 & $2018^{*}$ & $2019^{* 8}$ \\
\hline $\begin{array}{l}\text { Pertanian, Peternakan, } \\
\text { Perburuan, dan Jasa Pertanian }\end{array}$ & 1,10 & 1,13 & 1,14 & 1,03 & 1,02 & 1,32 & 1,39 & 1,42 & 1,43 & 1,47 \\
\hline - Tanaman Pangan & 0,67 & 0,71 & 0,71 & 0,66 & 0,62 & 0,83 & 0,85 & 0,85 & 0,86 & 0,81 \\
\hline - Tanaman Hortikultura & 0,83 & 0,86 & 0,89 & 1,02 & 1,03 & 1,40 & 1,58 & 1,60 & 1,54 & 1,61 \\
\hline - Perkebunan & 1,29 & 1,32 & 1,30 & 1,18 & 1,02 & 1,15 & 1,12 & 1,12 & 1,14 & 1,12 \\
\hline - Petemakan & 1,64 & 1,65 & 1,67 & 1,68 & 1,69 & 2,29 & 2,41 & 2,38 & 2,51 & 2,64 \\
\hline $\begin{array}{l}\text { - Jasa Pertanian dan } \\
\text { Perburuan }\end{array}$ & 1,11 & 1,12 & 1,12 & 1,16 & 1,09 & 1,47 & 1,56 & 1,51 & 1,57 & 1,68 \\
\hline Kehutanan & 0,76 & 0,79 & 0,80 & 0,76 & 0,73 & 0,94 & 0,97 & 1,02 & 1,05 & 1,10 \\
\hline Perikanan & 1,86 & 1,85 & 1,86 & 2,01 & 2,07 & 2,72 & 2,77 & 2,87 & 2,95 & 2,99 \\
\hline
\end{tabular}

* Angka Sementara

** Angka Sangat Sementara

Sumber: Diolah, 2020

Tabel 4. Hasil Perhitungan Location Quotient Luas Areal Perkebunan Kebupaten Minahasa Utara

\begin{tabular}{lcccccccccc}
\hline \multicolumn{1}{c}{ Komoditas } & $\mathbf{2 0 1 0}$ & $\mathbf{2 0 1 1}$ & $\mathbf{2 0 1 2}$ & $\mathbf{2 0 1 3}$ & $\mathbf{2 0 1 4}$ & $\mathbf{2 0 1 5}$ & $\mathbf{2 0 1 6}$ & $\mathbf{2 0 1 7}$ & $\mathbf{2 0 1 8}$ & $\mathbf{2 0 1 9}$ \\
\hline Kelapa & 1.33 & 1.35 & 1.32 & 1.28 & 1.27 & 1.27 & 1.29 & 1.35 & 1.27 & 1.50 \\
Kopi & 0.06 & 0 & 0.07 & 0.05 & 0.05 & 0.05 & 0 & 0 & 0 & 0 \\
Kakao & 0.05 & 0 & 0.09 & 0.23 & 0.23 & 0.24 & 0 & 0.01 & 0 & 0 \\
Cengkeh & 0.34 & 0.31 & 0.30 & 0.32 & 0.32 & 0.33 & 0.33 & 0.30 & 0.35 & 0 \\
Pala & 0.44 & 0.41 & 0.35 & 0.80 & 0.89 & 0.80 & 0.87 & 0.62 & 1.28 & 0 \\
Vanili & 0 & 0 & 0.23 & 0.86 & 0.90 & 1.03 & 1.11 & 0 & 0 & 0 \\
Jambu Mede & 0 & 0 & 5.02 & 4.93 & 4.49 & 4.56 & 1.48 & 0 & 0 & 0 \\
Aren & 0 & 0 & 0.80 & 0.95 & 0.95 & 0.99 & 1.00 & 0 & 0 & 0 \\
\hline
\end{tabular}

Sumber: Diolah, 2020

Tabel 5. Hasil Perhitungan Location Quotient Produksi Perkebunan Kebupaten Minahasa Utara

\begin{tabular}{lcccccccccc}
\hline \multicolumn{1}{c}{ Komoditas } & $\mathbf{2 0 1 0}$ & $\mathbf{2 0 1 1}$ & $\mathbf{2 0 1 2}$ & $\mathbf{2 0 1 3}$ & $\mathbf{2 0 1 4}$ & $\mathbf{2 0 1 5}$ & $\mathbf{2 0 1 6}$ & $\mathbf{2 0 1 7}$ & $\mathbf{2 0 1 8}$ & $\mathbf{2 0 1 9}$ \\
\hline Kelapa & 1.18 & 1.07 & 1.10 & 1.09 & 1.07 & 1.12 & 1.12 & 1.10 & 1.10 & 1.21 \\
Kopi & 0.04 & 0 & 0.03 & 0 & 0 & 0 & 0 & 0 & 0 & 0 \\
Kakao & 0.15 & 0 & 0.17 & 0.15 & 0.15 & 0.19 & 0.20 & 0 & 0 & 0 \\
Cengkeh & 0.18 & 0 & 0.32 & 0 & 0.55 & 0.19 & 0.18 & 0 & 0 & 0 \\
Pala & 0.16 & 0.13 & 0.16 & 0.14 & 0.13 & 0.12 & 0.12 & 0.04 & 0.05 & 0 \\
Vanili & 0 & 0 & 0 & 0 & 0 & 0 & 0 & 0 & 0 & 0 \\
Jambu Mede & 0 & 0 & 6.23 & 5.35 & 5.18 & 5.27 & 5.34 & 0 & 0 & 0 \\
Aren & 0 & 0 & 0.64 & 0.71 & 0.69 & 1.18 & 1.20 & 0 & 0 & 0 \\
\hline Sumber: Diolah, 2020 & & & & & & & & &
\end{tabular}

Tabel 3 menunjukkan bahwa sub sektor perkebunan merupakan subsektor basis dengan hasil LQ > 1 dari tahun 2010-2019. Hal ini berarti bahwa sub sektor perkebunan merupakan sumber pertumbuhan ekonomi, memiliki keunggulan komparatif, dapat memenuhi kebutuhan provinsi serta dapat melakukan ekspor.

Nilai LQ dari perkebuanan pada tahun 2019 adalah 1,12 . Sub sektor perkebunan memiliki nilai LQ terbesar pada tahun 2011 dengan nilai 
1,31 dan terendah pada tahun 2014 dengan nilai LQ sebesar 1,02. Sub sektor lainnya diluar sektor pertanian yang memiliki nilai LQ lebih dari satu yaitu peternakan, jasa pertanian dan perburuan, perikanan sedangkan untuk tanaman hortikultura pada tahun 2010-2011 bukan sektor basis mengalami kenaikan pada tahun 2013 dan mimiliki nilai LQ > 1 dan bertahan sampai 2019, untuk kehutanan pada tahun 2017 menjadi sektor basis samapai 2019 sebelumnya dari tahun 2010-2016 bukanlah sektor basis.

Hasil anaisis Location Quotient terhadap masingmasing jenis tanaman perkebunan data dilihhar pada Tabel 2 dan Tabel 3.

Tabel 4 menunjukkan bahwa kelapa merupakan tanaman perkebunan yang konsisten dengan nilai LQ > 1 sedangkan tanaman perkebunan lainnya mengalami naik turun disetiap tahunnya. Jambu mete selama 5 tahun merupakan salah satu tanaman perkebunan unggulan dari tahun 2012-2016 namun di tahun 2016 mengalami penurunan secara drastis sebesar $67.54 \%$ dan sejak tahun 2017 bernilai nol. Pala pada tahun 2009 - 2017 memiliki nilai LQ $<1$ namun pada tahun 2018 memiliki kenaikan sehingga memiliki nilai LQ $>1$. Sedangkan untuk kopi, kakao, dan cengkeh disetiap tahunnya memiliki nilai $\quad$ LQ $<1$ artinya bukan sektor basis.
Dari hasil analisis location quotient untuk peroduksi perkebunan (ton) seperti halnya dengan Tabel 5 kelapa selama 10 tahun terakhir ini memiliki nilai LQ > 1 . Untuk jambu mete dari tahun 2012-2016 memiliki nilai LQ > 1 . Aren di tahun 2015 dan 2016 memiliki nilai LQ > 1 . Untuk komoditas lainnya seperti vanili, kopi, kakao, cengkeh, pala memiliki nilai LQ $<1$ yang mengartikan kalau komoditas tersebut bukan atau non unggulan.

2) Hasil Analisis Shift Share

Hasil Analisis shift share sub sector perkebunan selang tahun 2010-2019 dapat dilihat pada Tabel 6.

Berdasarkan analisis Shift Share, laju pertumbuhan ekonomi (Dij) untuk sub sector perkebunan memiliki kinerja ekonomi yang baik karena nilai menunjukan hasil positif namun di tahun 2012-2013 mnunjukan nilai negatif sebesar 12500.07 yang artinya kinerja ekonomi atau laju pertumbuhan yang kurang baik.

Pada tahun 2010-2011 dan tahun 2013-2014, sub sektor perkebunan memiliki keunggulan kompetitif karena memiliki nilai (Cij) positif sehingga dapat berkompetitif dengan sektor lain. Sedangkan tahun 2011-2013 serta tahun 20142019 memiliki nilai negatif yang artinya sektor perkebunan tidak mimiliki keunggulan kompetitif dikarenakan nilai rij lebih kecil dari rin.

Tabel 6. Hasil Perhitungan Analisis Shift Share Perkebunan di Kabupaten Minahasa Utara

\begin{tabular}{ccccc}
\hline Tahun & Nij & Mij & Cij & Dij \\
\hline $2010-2011$ & 29771.26 & -3140.11 & 5085151 & 5111781.89 \\
$2011-2012$ & 30442.95 & 2523.29 & -5888.36 & 27077.88 \\
$2012-2013$ & 30295.85 & 2099.97 & -44895.9 & -12500.07 \\
$2013-2014$ & 29192.04 & 1086.56 & 12149.72 & 42428.33 \\
$2014-2015$ & 157158.94 & 28443.35 & -60805 & 124797.34 \\
$2015-2016$ & 44827.35 & 3432.81 & -24495 & 23765.12 \\
$2016-2017$ & 42518.46 & 3391.21 & -14604.4 & 31305.29 \\
$2017-2018$ & 39905.02 & -1473.80 & -104.271 & 38326.95 \\
$2018-2019$ & 39979.52 & 2496.80 & -18292.9 & 24183.43 \\
\hline
\end{tabular}

Sumber: Diolah, 2020

Sektor perkebunan di Minahasa Utara memiliki pertumbuhan sektor yang relatif cepat (Mij) namun ditahun 2010-2011 nilai PDRB perkebunan provinsi di tahun akhir (2011) memiliki angka lebih kecil dari tahun awal (2010) dan tahun 2017-2018 nilai PDRB kabupaten dan provinsi tahun akhir (2018) memiliki angka lebih kecil dari tahun awal (2017) sehingga sektor perkebunan relatif lambat karena memiliki nilai negatif. 
Untuk sepuluh tahun terakhir ini sektor perkebunan berpengaruh positif (Nij) terhadap perekonomian di Minahasa Utara. Hasil dari perhitungan analisis shift share menunjukan sektor perkebunan memiliki peran yang positif meskipun tidak memiliki keunggulan kompetitif.

3) Hasil Analisis Kontribusi Sub Sektor

Perkebunan

Kontribusi sektor-sektor terhadap perekonomian Minahasa Utara dapat dilihat pada Tabel 7.

Dari hasil perhitungan analisis kontribusi diatas menunjukkan sektor pertanian memberikan kontribusi yang paling besar terhadap perekonomian Minahasa Utara dan merupakan nilai tertinggi dengan nilai $31.10 \%$ tahun 2010 dan $25.85 \%$ pada tahun 2018 yang merupakan nilai terendah. Untuk sektor kontruksi menunjukan perkembangan yang baik dengan disetiap tahunnya mengalami penigkatan terus menerus selama sepuluh tahun terakhir periode 2010-2019. Sedangkan untuk sub sektor perkebunan disetiap tahunnya mengalami penurunan. Untuk sektor jasa perusahaan memiliki nilai kontribusi paling sedikit namun stabil dengan nilai 0.02 dari tahun 20102019.

Tabel 7. Kontribusi Sektor-Sektor di Kabupaten Minahasa Utara ADHK

\begin{tabular}{|c|c|c|c|c|c|c|c|c|c|c|}
\hline Lapang Usaha & 2010 & 2011 & 2012 & 2013 & 2014 & 2015 & 2016 & 2017 & $2018^{*}$ & $2019 * *$ \\
\hline Pertanian, Kehutanan, dan & 31.10 & 29.71 & 29.73 & 29.45 & 28.99 & 27.88 & 27.07 & 26.54 & 25.85 & 25.91 \\
\hline $\begin{array}{l}\text { Perikanan } \\
\text { - Perkebunan }\end{array}$ & 9.35 & 8.04 & 8.03 & 7.32 & 6.20 & 6.00 & 5.72 & 5.62 & 5.08 & 4.89 \\
\hline Pertambangan dan Penggalian & 9.96 & 10.14 & 10.18 & 10.30 & 10.30 & 10.59 & 10.79 & 10.90 & 11.36 & 11.64 \\
\hline Industri Pengolahan & 13.95 & 14.10 & 14.15 & 14.04 & 13.72 & 13.51 & 12.75 & 13.35 & 13.40 & 12.68 \\
\hline Pengadaan Listrik dan Gas & 0.10 & 0.10 & 0.11 & 0.11 & 0.12 & 0.12 & 0.13 & 0.13 & 0.13 & 0.13 \\
\hline $\begin{array}{l}\text { Pengadaan Air, Pengelolaan } \\
\text { Sampah, Limbah dan Daur Ulang }\end{array}$ & 0.09 & 0.09 & 0.09 & 0.09 & 0.08 & 0.08 & 0.08 & 0.07 & 0.07 & 0.07 \\
\hline Konstruksi & 12.78 & 13.17 & 13.30 & 13.38 & 13.73 & 14.35 & 15.03 & 15.21 & 15.17 & 15.20 \\
\hline $\begin{array}{l}\text { Perdagangan Besar dan Eceran; } \\
\text { Reparasi Mobil dan Sepeda } \\
\text { Motor }\end{array}$ & 9.21 & 9.48 & 9.10 & 9.26 & 9.49 & 9.53 & 9.58 & 9.37 & 9.39 & 9.56 \\
\hline Transportasi dan Pergudangan & 4.06 & 4.10 & 4.14 & 4.13 & 4.19 & 4.24 & 4.30 & 4.37 & 4.44 & 4.52 \\
\hline $\begin{array}{l}\text { Penyediaan Akomodasi dan } \\
\text { Makan Minum }\end{array}$ & 0.96 & 0.97 & 0.97 & 1.00 & 1.02 & 1.04 & 1.09 & 1.09 & 1.11 & 1.10 \\
\hline Informasi dan Komunikasi & 1.95 & 1.91 & 1.91 & 1.95 & 2.00 & 2.05 & 2.12 & 2.08 & 2.12 & 2.19 \\
\hline Jasa Keuangan dan Asuransi & 0.80 & 0.81 & 0.83 & 0.81 & 0.78 & 0.76 & 0.87 & 0.94 & 0.92 & 0.90 \\
\hline Real Estate & 5.27 & 5.42 & 5.44 & 5.45 & 5.59 & 5.74 & 5.91 & 6.05 & 6.21 & 6.27 \\
\hline Jasa Perusahaan & 0.02 & 0.02 & 0.02 & 0.02 & 0.02 & 0.02 & 0.02 & 0.02 & 0.02 & 0.02 \\
\hline $\begin{array}{l}\text { Administrasi Pemerintahan, } \\
\text { Pertahanan dan Jaminan Sosial } \\
\text { Wajib }\end{array}$ & 3.75 & 3.83 & 3.91 & 3.90 & 3.98 & 4.04 & 4.06 & 3.63 & 3.44 & 3.24 \\
\hline Jasa Pendidikan & 2.78 & 2.84 & 2.84 & 2.84 & 2.77 & 2.82 & 2.88 & 2.89 & 2.95 & 3.05 \\
\hline $\begin{array}{l}\text { Jasa Kesehatan dan Kegiatan } \\
\text { Sosial }\end{array}$ & 2.61 & 2.69 & 2.66 & 2.65 & 2.60 & 2.63 & 2.70 & 2.72 & 2.78 & 2.86 \\
\hline Jasa lainnya & 0.60 & 0.63 & 0.63 & 0.63 & 0.61 & 0.62 & 0.63 & 0.63 & 0.65 & 0.67 \\
\hline Jumlah & 100 & 100 & 100 & 100 & 100 & 100 & 100 & 100 & 100 & 100 \\
\hline
\end{tabular}

* Angka Sementara

** Angka Sangat Sementara

Sumber: Diolah, 2020 
Tabel 8. Kontribusi Sub Sektor Pertanian di Kabupaten Minahasa Utara ADHK

\begin{tabular}{|c|c|c|c|c|c|c|c|c|c|c|}
\hline Lapangan Usaha & 2010 & 2011 & 2012 & 2013 & 2014 & 2015 & 2016 & 2017 & $2018^{*}$ & $2019^{* *}$ \\
\hline Pertanian, Peternakan, & & & & & & & & & & \\
\hline Perburuan, dan Jasa & 17.76 & 16.51 & 16.53 & 14.83 & 14.13 & 14.10 & 14.03 & 13.70 & 13.14 & 12.94 \\
\hline \multicolumn{11}{|l|}{ Pertanian } \\
\hline Tanaman Pangan & 3.15 & 2.99 & 2.79 & 2.51 & 2.19 & 2.09 & 2.07 & 1.99 & 1.92 & 1.65 \\
\hline Tanaman Hortikultura & 1.67 & 1.81 & 1.93 & 2.23 & 2.18 & 2.24 & 2.39 & 2.34 & 2.27 & 2.31 \\
\hline Perkebunan & 9.35 & 8.04 & 8.03 & 7.32 & 6.20 & 6.00 & 5.72 & 5.62 & 5.08 & 4.89 \\
\hline Peternakan & 3.15 & 3.24 & 3.36 & 3.32 & 3.32 & 3.52 & 3.61 & 3.51 & 3.63 & 3.84 \\
\hline $\begin{array}{l}\text { Jasa Pertanian dan } \\
\text { Perburuan }\end{array}$ & 0.29 & 0.27 & 0.27 & 0.27 & 0.24 & 0.26 & 0.26 & 0.24 & 0.24 & 0.24 \\
\hline Kehutanan & 0.55 & 0.53 & 0.51 & 0.47 & 0.40 & 0.36 & 0.35 & 0.33 & 0.32 & 0.29 \\
\hline Perikanan & 12.79 & 12.68 & 12.69 & 14.15 & 14.47 & 13.41 & 12.68 & 12.51 & 12.39 & 12.68 \\
\hline
\end{tabular}

* Angka Sementara

** Angka Sangat Sementara

Sumber: Diolah, 2020

Tabel 8 merupakan kontribusi subsektorsubsektor di Kabupaten Minahasa Utara. Sub sektor perikanan memiliki nilai kontribusi paling tinggi dan merupakan penyumbang terbesar untuk kontribusi bagi sektor pertanian. Pada periode 2010-2019 sub sektor perkebunan merupakan sub sektor kedua yang memiliki kontribusi terbesar dalam sektor pertanian namun disetiap tahun mengalami penurunan, dari tahun 2010-2019 dan jika dibandingkan dari tahun awal 2010 dan tahun akhir 2019 sektor perkebunan sudah mengalami penurunan sebesar $52.36 \%$ dan ini merupakan nilai yang cukup besar karena sudah melebihi 50 persen. Sebagai gambaran konversi lahan pertanian berdasarkan penelitian dari Lapatandau dkk (2017) pada tahun 2013 ke 2014 Kabupaten Minahasa Utara telah mengalami penurunan luasan tegal atau kebun dari 26.189 menjadi 12.297 hektar atau berkurang sebesar 13.892 hektar. Hal ini terutama disebabkan oleh adanya konversi lahan tegal atau kebun menjadi lahan non pertanian seperti lahan pemukiman, pabrik dan pergudangan serta pembangunan jalan tol Manado - Bitung.

\section{KESIMPULAN DAN SARAN}

\section{Kesimpulan}

Dari hasil penelitian dan perhitungan yang telah dilakukan dengan menggunakan analisis Location Quotient (LQ), analisis Shift Share dan analisis kontribusi di Kabupaten Minahasa Utara tahun 2010-2019 dapat diambil kesimpulan sebagai berikut:

1) Sub sektor perkebunan merupakan sub sektor basis di Kabupaten Minahasa Utara dan mimiliki nilai LQ lebih dari 1 dan mampu manghasilkan barang dan jasa untuk konsumsi lokal maupun mengekspor keluar wilayah Kabupaten Minahasa Utara dan komoditi basis di kabupaten Minahasa Utara adalah kelapa. Selama periode 10 tahun terakhir (2010-2019) sektor perkebunan mengalami fluktuasi yang diakibatkan dari pengurangan produksi dan luas lahan perkebunan di Kabupaten minahasa Utara.

2) Sub sektor perkebunan tidak memiliki keunggulan kompetitif untuk tahun 2011-2019 namun memberi pengaruh positif dan laju 
pertumbuhan yang baik untuk perekonomian Minahasa Utara.

3) Sub sektor perkebunan masih memberi hasil positif untuk kontribusi Kebupaten Minahasa Utara namun berdasarkan analisis kontribusi sektor perkebunan setiap tahun mengalami penurunan kontribusi yang dikarenakan berkurangnya lahan perkebunan dan produksi beberapa komoditi perkebunan di Kabupaten Minahasa Utara.

\section{Saran}

Dengan adanya penelitian ini, diharapkan sektor perkebunan terus mampu menjadi sektor basis, dan untuk pemerintah Kabupaten Minahasa Utara kiranya lebih memperhatikan sektor perkebunan, dengan cara memberi bantuan kepada petani dan lahan kosong dapat dimanfaatkan menjadi perkebunan agar produksi tenaman perkebunan meningkat dan agar sektor perkebunan tidak berubah menjadi sektor non basis dan bisa memberi kontribusi lebih besar terhadap perekonomian Kabupaten Minahasa Utara.

\section{DAFTAR PUSTAKA}

BPS. Database PDRB Menurut Lapangan Usaha Kabupaten Minahasa Utara 2010-2014.

Fatihudin, D.. 2019. Membedah Investasi Menui Geliat Ekonomi. Deepublish. Cet. 1, Yogyakarta.

Haryanto, T.. 2009. Ekonomi Pertanian. Airlangga University Perss. Cet.1, Surabaya.

Lapatandau, Y, A., G. A. J. Rumagit dan C. B. D. Pakasi.. 2017. Alih Fungsi Lahan Pertanian Di Kabupaten Minahasa Utara. Jurnal. Univesitas Sam Ratulangi. Manado, 13 (2A)

Prasetyo, W. L.. 2019. Perbedaan Pertanian dan Perkebunan dan Jenis Tanaman yang Ditanam. Mesinpertanian.id. www.mesinpertanian.id/ tanggal akses 30-01-2021

Sattar.. 2018. Buku Ajaran Perekonomian Indonesia. Deepublish, Yogyakarta.

Suryantini, A., S. Hartono., A. Nurhayati., dan W. Widyaningsih.. 2015. Peran Sektor Pertanian Terhadap Perekonomian Daerah Istimewa Yogyakarta (Aanalisis Input-Output Daerah Istimewa Yogyakarta Untuk Komoditas Tebu). Jurnal. Universitas Gadjah Mada. Yogyakarta, 4 (1).

Suwarto, Y., Octavianty., dan S. Hermawati.. 2014. Top 15 Tanaman Perkebunan. Swadaya, Cet.1, Jakarta.
Undang-Undang Republik Indonesia Nomor 18 Tahun 2004 Tetang Perkebunan

Zaini, A.. 2019. Perkembangan Sektor Unggulan di Kalimantan Timur. CV Budi Utama, Yogyakarta. 